\title{
Notes sobre el seminari internacional La importància estratègica de la formació de les persones adu/tes organitzat per la UIMP a Castelló
}

Notas sobre el seminario internacional La importancia estratégica de la formación de las personas adultas organizado por la UIMP en Castellón

\section{Notes on the international seminar 'The strategic importance of adult education' organized by the UIMP in Castellon}

Agustí Pascual Cabo'

Centre Específic d'Educació a distància de la

Comunitat Valenciana

\section{Resum}

Aquest text és un exercici de memòria que recrea els moments viscuts en abril de 1995, com assistent al seminari internacional de la UIMP La importància estratègica de la Formació de Persones Adultes, en la jornada Castelló. Aquella participació va donar l'oportunitat, no sols d'escoltar la conferència de Freire, però de poder conversar amb Basil Bernstein al finalitzar la seua ponència, com un dels conferenciants convidats. El present text recupera per primera vegada l'entrevista de l'autor amb Berstein sobre el discurs pedagògic en relació amb l’educació de persones adultes.

Paraules clau: Bernstein, codis, curriculum, discurs pedagògic, educació de persones adultes

\section{Resumen}

Este texto es un ejercicio de memoria que recrea los momentos vividos en abril de 1995, como asistente al seminario internacional de la UIMP La importancia estratégica de la Formación de Personas Adultas, en la jornada de Castellón. Esa participación dio la conferencia que Paulo Freire impartió en Castellón. Esa participación supuso la oportunidad, no solo de escuchar la conferencia de Freire, sino de poder conversar con Bernstein al finalizar su ponencia, como uno de los conferenciantes invitados El presente texto recupera por primera vez la entrevista del autor con Bernstein sobre el discurso pedagógico en relación con la educación de personas adultas.

Palabras clave: Bernstein, códigos, curriculum, discurso pedagógico, educación de personas adultas

$1 \quad$ Agustí Pascual Cabo és Doctor en Pedagogia. Ha sigut professor en el Centre Específic d’Educació a Distància de la Comunitat Valenciana [CEEDCV] i en el Departament de Didàctica i Organització Escolar de la Universitat de València. Guardó del XIX Premi Ciutat de Dénia per a la Formació de Persones Adultes, atorgat en 2016. 
D’aquell seminari [Castelló, abril de 1995] m’agradaria destacar sobretot la reflexió teòrica que suposà personalment el participar-hi. A l'any següent, juliol de 1996, presentí la tesi doctoral Conceptualització curricular en Educació de Persones Adultes: de la prescripció a la construcció discursiva ${ }^{2}$ que em va dirigir el Dr. Francisco Beltrán Llavador. Com totes les tesis fou un treball molt intens i que tingué, entre altres referents, a personalitats que intervingueren en el seminari. Entre les quals destacaria fonamentalment a Paulo Freire i a Basil Bernstein pel que respecta a qüestions teòriques, entre d'altres, que fonamentaven el desenvolupament del treball d'investigació.

La intervenció de Freire fou un discurs, com no podia ser d'altra manera, molt interessant però a la vegada molt entranyable perquè la seua obra era i és un referent constant de tots els qui treballem o hem treballat en educació de persones adultes. És per això que m'atreviria a fer un suggeriment de lectura, i per què no de relectura, tant de la seua obra com d'altres obres publicades per l'Institut Paulo Freire [IPF], per part de les "noves generacions d'educadors" en l'àmbit de l'educació [i no només de persones adultes]. Tanmateix per qüestió d'espai, i perquè considere que l'obra de Freire la comentaran d'altres, vull centrar-me en Bernstein ja que vaig poder parlar personalment després de la seua intervenció a Castelló i també perquè fou, tal com tractaré de mostrar en aquestes notes, una de les aportacions teòriques per a fonamentar l'especificitat del currículum en educació de persones adultes.

Considere que cal recordar molt resumidament que, com desenvolupa en la seua obra Bernstein, el dispositiu pedagògic, i en concret l'estructura curricular, té unes regles internes que regulen la comunicació pedagògica i que operen de forma selectiva sobre el potencial significatiu dels coneixements. És per esta raó que no són independents de les ideologies i són considerades com la condició de la producció, de la reproducció i de la transformació de la cultura. Si són importants els continguts que es transmeten també ho són les estructures que construeixen aquells continguts, ja que en la mesura que comprenguem les construccions estarem en disposició de transformar o de modificar els propis continguts. Metafòricament, esta estructura curricular proporciona la gramàtica intrínseca del dispositiu pedagògic a través de:

a. Regles distributives que regulen la relació entre el poder, els grups socials, les formes de consciència i la pràctica; en elles es determinen quins discursos són pensables i/o impensables i quines possibilitats d'acció s'ofereixen,

b. Regles de recontextualització que regulen la constitució del discurs pedagògic i creen les possibilitats de transmissió de la cultura a través de la inserció d'un discurs instructiu [competències especialitzades] en un discurs regulador [principi d'ordre, de relació i d'identitat] d'ordre social,

c. Regles d'avaluació que estan construïdes en la pràctica pedagògica i fan referència a la jerarquia [entre el qui ensenya i el qui aprèn], al ritme i a la seqüència dels sabers en els processos de l'ensenyament i de l'aprenentatge i també als criteris o tipus de comunicació.

Les regles distributives determinen allò que és "pensable" d'allò "impensable" però fonamentalment qui pot desenvolupar allò "impensable", allò "impossible", és per tant una distribució de poder, en

2 Bona part dels resultats d'esta tesi es van arreplegar en la publicació: Hacia una sociología curricular en Educación de Personas Adultas. Barcelona: Octaedro, 2000. 
benefici dels interessos de l'ordre social que és el que crea, manté i legitima la classificació social de les classes. Però com es tradueix esta regla a l'educació de persones adultes? Allò pensable és el que es dóna en la institució escolar, és el que anomena Bernstein el coneixement "mundà", però l' "impensable" que anomena "esotèric", es produeix en els nivells superiors del sistema educatiu [universitats], la divisió i la regulació dels quals està marcada pel poder institucional de codis en agències i agents especialitzats [instàncies de decisió i de determinació). La línia que separa el coneixement "mundà" de l'esotèric" és determina per un període, un espai i un temps determinats, però també i fonamentalment pels "codis elaborats", que venen a ser els mecanismes per a pensar allò "impensable", allò "impossible" i que aporten un significat regulador i de distribució. En l'educació de persones adultes la separació de "coneixements" per aqueixa línia pot donar pas a dues propostes:

a. Reforçar aqueixa, i convertir l'educació de persones adultes en "l'escolarisme", en la via "compensadora" i reproductiva socialment i,

b. reconvertir i reconstruir aqueixa, i possibilitar un camí per a "repensar" allò "impensable" i per a facilitar un dispositiu pedagògicament democràtic.

Si considerem l'estructura curricular i en concret la recontextualització com la regla que insereix un discurs instructiu [habilitats de diversos tipus] en un discurs d'ordre social, de manera que l'últim domina sobre el primer, el discurs regulatiu "recontextualitza" els "codis elaborats" en un procés didàctic de descol-locació i de recol-locació dels significats originals que el porten a una pràctica imaginària, a uns significants distints dels anteriors, d'acord amb els principis dominants d'una determinada societat.

En esta "regla recontextualitzadora" en la qual predomina el discurs regulatiu, poden veure's alterats, la seua classificació i el seu emmarcament, per un discurs pedagògic que tracte els significats originals en originals significants, desfent així l'asseveració de Bernstein, "els qui reprodueixen el coneixement legítim institucionalitzen allò "pensable", mentre que els qui produeixen coneixement legítim institucionalitzen allò "impensable".

La finalitat de la gramàtica de l'educació de persones adultes ha d'equiparar els discursos apropiats amb els discursos imaginatius. Les regles del discurs pedagògic de l'educació de persones adultes no intenten tant inserir el "discurs instruccional" en el "discurs regulatiu" com recontextualitzar estos discursos, encara que cal admetre que existeix un camp de la recontextualització oficial dominat per l'Estat i els seus agents i un camp de recontextualització pedagògica. Estos camps són un camp de lluita i un element fonamental per a analitzar la institucionalització de l'educació.

Quan Bernstein explicà l'estructura del discurs pedagògic en el seminari a Castelló, abril de 1995, tractàrem d'aplicar aquella estructura a les experiències de l'educació de persones adultes i al desenvolupament de la investigació. Les preguntes que li vaig fer personalment foren:

1. Quan parla de "text" es refereix al currículum, entenent aquest com els coneixements valuosos i adequats? La resposta fou afirmativa però ampliant els coneixements valuosos i adequats a tots aquells que es desenvolupen socialment.

2. L'educació de persones adultes institucional i el currículum que desenvolupa, ¿no reproduirà el "discurs mitològic" i de "violència simbòlica" o hi ha algun aspecte o element de l'estructura dels discurs pedagògic que trenque aquella reproducció i faça el dispositiu pedagògic 
[regles] no siga estable? Tot i reconeguent la seua poca experiència en l'educació de persones adultes, començà a "recontextualitzar" el seu discurs, admetent que la dominació del "discurs regulatiu" que transforma un "discurs original" en una altre "imaginable" pot no donar-se en l'educació de persones adultes, és a dir, que determinats coneixements no es recontextualitzen. Posà l'exemple del treball de camioner en el qual determinats coneixements originals no tenen per què esdevenir imaginaris. La qual cosa ens permeté afirmar-nos en considerar l'especificitat del currículum de l'educació de persones adultes.

Si les formes de coneixements que es treballen a l'escola constitueixen un producte o una representació específica de la cultura, tal com s'explicita des del discurs pedagògic; el sistema de coneixements que proposàrem al treball d'investigació, i que constitueix l'objecte del discurs pedagògic de l'educació de persones adultes, no necessàriament ha de derivar-se d'una representació específica de la cultura sinó que contràriament ha de sustentar-se en ella, de tal manera que les funcions i regles de l'educació de persones adultes responguen tant a les pròpies del context educatiu com a les pròpies fonts de la seua procedència social. És per esta raó que la física, la música, la història, la informàtica... tenen, per una part un component igual al de la producció de coneixement [cultural], però per altra també una singularitat donada pel propi discurs pedagògic que no té res a veure amb l'anterior i, per tant, des d'este no es pot dir que coincideixen els coneixements de física, música, història, informàtica... El sistema de coneixements [socialseducatius] s'uniria i es complementaria tant pel que fa a la producció com al desenvolupament; i tindria una repercussió fonamental i bàsica en les relacions, les comunicacions i els papers dels agents educatius així com en les instàncies curriculars. El dispositiu pedagògic o estructura curricular media entre el poder i el sistema de coneixements i entre este i la consciència ["procés de conscienciació freiriana"]. La pròpia estructura del discurs pedagògic de l'educació de persones adultes fonamentà les nostres propostes curriculars que complementen la proposta de Bernstein. Des de les nostres propostes en la investigació sobre els conceptes estructurals del currículum [estructura curricular, principis curriculars i codis curriculars o format curricular] es tenen en compte les anomenades teories d'oposició (de correspondència i de reproducció) però sobretot la propositivitat de transformació de les pautes de regulació, de control i de dominació de la construcció curricular tradicional.

Possiblement determinats conceptes o idees exposats necessiten d'un major desenvolupament teòric per a la seua comprensió però considere que el propòsit d'estes notes és valorar la importància pedagògica de la intervenció de Bernstein. 